\title{
LAST WORDS
}

With this number the Journal begins a new feature as part of the section devoted to gifts and acquisitions, namely a listing in each issue of a few special needs of the Library. This list may include certain odd numbers or volumes missing from the files of important periodical series, some out of print books or sets, or occasional pamphlets or other miscellanies needed to fill in gaps in its more valuable collections. It is hoped that this may help the Friends of the Rutgers University Library (whose journal this is, let us remind them) to determine how they can best aid in building the collections. In the field of early American literature and history and particularly of New Jerseyana (of which the Library already has a rich store of materials) this may be especially useful. It is not too fantastic to suppose that if all the Friends should set themselves to search their own libraries and attics and those of their neighbors they might turn up the very items which the Library needs to complete a series of books, magazines, pamphlets, or broadsides. And even when it is not a question of items most likely to be "naturals" for New Jersey attics, several hundred bookhunters among the Friends may help to locate things which the Librarian and his staff do not have time to search for in the byways.

It is our belief that every library ought to have several realms of specialization. All the great university and private research libraries have such areas of strength. And nothing is truer (or more just) with respect to a library than the Biblical principle "to him that hath shall be given." Every library ought to build, and be aided in building, in the areas of its specialization and its most important collections. Historical records and letters of a particular period or person should go to a library which already has a large collection. With modern facilities for photographic reproduction and the common courtesies of American libraries it is not too difficult for serious students everywhere to have access to all major collections in their fields. But where possible it is desirable to keep collections together. It will be the endeavor of the Journal to keep its friends informed both of its specific needs and of the fields in which it is desirous and worthy of growing. 